\title{
Søvnmangel hos barn øker risiko for overvekt
}

\section{$\emptyset \mathrm{kt}$ BMI hos barn ved redusert søvn kan skyldes økt fettdeponering}

Barn sover mindre nå enn tidligere, og dette ses i sammenheng med den dramatiske økningen i overvekt hos barn og unge. Nå har forskere i New Zealand i en longitudinell

studie undersøkt om redusert søvn er assosiert med forskjeller i kroppssammensetning og risiko for overvekt hos barn (1).

244 barn fra en fødselskohort ble fulgt opp

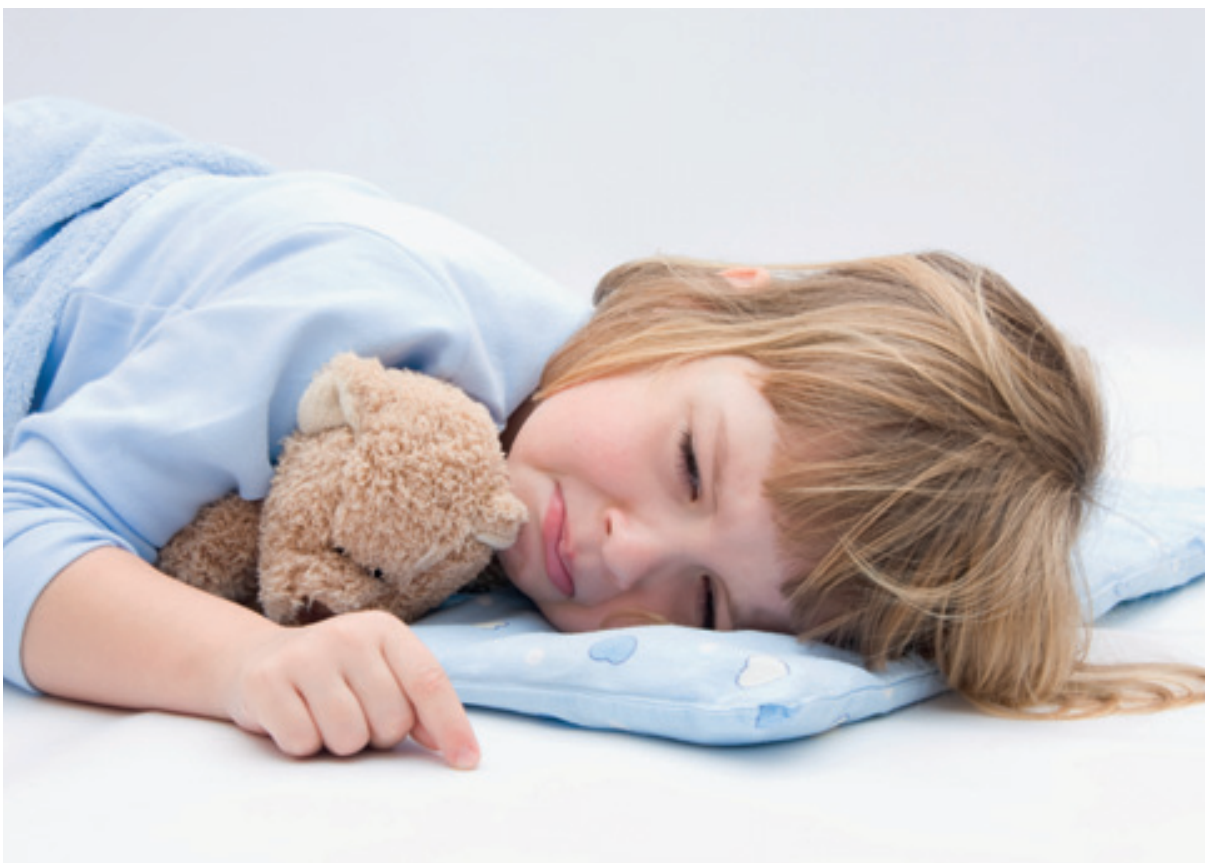

Illustrasjonsfoto Istockphoto

\section{Hvordan behandle plutselig hørselstap?}

\section{Peroral steroidbehandling er \\ førstevalg ved idiopatisk plutselig \\ hørselstap, men intratympanisk \\ administrasjon kan tilbys i spe- \\ sielle tilfeller.}

Idiopatisk plutselig oppstått sensorinevralt hørselstap har vært behandlet med orale steroider i mer enn 30 år, men intratympanisk steroidbehandling har også vært forsøkt. I en prospektiv, randomisert non-inferiority-studie fra Harvard Medical School har man sammenliknet de to behandlingsformene (1).

Studien omfattet 250 pasienter som hadde unilateralt sensorinevralt hørselstap $\geq 50 \mathrm{~dB}$ i opptil 14 dager. Deltakerne fikk enten oral fra tre til sju års alder. Etter justering for konfunderende faktorer var hver ekstra time søvn i alderen 3-5 år assosiert med en reduksjon i BMI på 0,48 (95\% KI 0,01-0,96) og en redusert risiko for å være overvektig (BMI > 85prosentilen) på $0,39(0,24-0,63)$. Forskjellene i BMI ble i større grad forklart av forskjeller $\mathrm{i}$ indeks for fettmasse enn fettfri masse.

- Studien hadde relativt få deltakere og en deltakelsesrate på kun $59 \%$, men er interessant fordi man benyttet objektive mål på søvn og inkluderte informasjon om kroppssammensetning, sier seksjonsoverlege Pétur B. Júlíusson ved Barneklinikken, Haukeland universitetssykehus, Bergen.

- Mange spørsmål er likevel ubesvarte. Foreligger det en kausal sammenheng mellom redusert søvn og overvekt? Hvordan fører mindre søvn til mer overvekt? Fører forbedring av søvnmønsteret til vektreduksjon? Det er uansett grunn til å anbefale god søvnrytme hos barn generelt. Mange barn med vektproblemer har en mangel på gode rutiner for mat, aktivitet og søvn. Her må foreldrene være bevisst sitt ansvar, sier Júlíusson.

\section{Trine B. Haugen}

trine.b.haugen@hf.hio.no

Tidsskriftet

\section{Litteratur}

1. Carter PJ, Taylor BJ, Williams SM et al. Longitudinal analysis of sleep in relation to $\mathrm{BMI}$ and body fat in children: the FLAME study. BMJ 2011; 342 d2712. parten av de intratympanisk behandlede pasientene først hadde fått orale steroider i 2-3 dager, sier Therese Ovesen, ved Øre-, næse- og halsafdelingen, Aarhus universitetshospital (2).

\section{Erlend Hem}

erlend.hem@medisin.uio.no

Tidsskriftet

kluderer med at begge behandlingsforme gir omtrent like gode resultater. Intratympanisk steroidbehandling er imidlertid mer kostbart og besværlig, og kan egne seg når oral prednisolon er kontraindisert.

- Studien underbygger de danske retningslinjene med orale steroider som primærvalg i behandlingen av idiopatisk plutselig hørselstap, og at intratympanisk administrasjon kun tilbys i særlige tilfeller. Undersøkelsen er imidlertid ikke optimalt designet, siden halv-
Litteratur

1. Rauch SD, Halpin CF, Antonelli PJ et al. Oral vs. intratympanic corticosteroid therapy for idiopathic sudden sensorineural hearing loss. JAMA 2011; 305: 2071 -9.

2. Høi-Hansen CE. Peroralt og intratympanisk steroid er næsten lige godt til idiopatisk pludseligt høretab. Ugeskr Læger 2011; 173: 1780. 